\title{
Digital Marketing in Culinary Tourism : A Case of Micro, Small and Medium Enterprises (MSMEs) in Indonesia
}

\author{
Eman Sulaiman', Adnane Derbani², Wiwiek Rabiatul Adawiyah ${ }^{3}$ \\ \{ emans.aero@gmail.com ${ }^{1}$,derbaniadnane@gmail.com² ${ }^{2}$,wiwiek.adawiyah@unsoed.ac.id ${ }^{3}$ ) \\ Jenderal Soedirman of University. Purwokerto-Central Java-Indonesia, STIE Cirebon -Indonesia ${ }^{1}$, \\ Jenderal Soedirman of University. Purwokerto-Central Java- Jenderal Soedirman of University \\ Purwokerto $^{3}$
}

\begin{abstract}
Effective use of Digital Marketing on micro small and Medium Enterprises (MSMEs). This paper aims to analyze the influence of Information Technology, Employee Skill, digital strategy to Digital Marketing in MSMEs. Data were drawn from using a questionnaire of culinary tourism businesses and stakeholders. A literature review supported empirical data. The paper finds that MSME has significantly different attitudes to Digital Marketing and cannot be regarded as a homogenous group for Digital Marketing initiatives. Rather, specific targeting would enhance participation and lead to more effective use. Using categories derived from the literature, a classification of five MSMEs groupings based on firms' motivations is proposed. It is recommended that utilize initiatives are targeted at two groups that have the need or desire to become enabled. The data begins from one area and thusly the assessment setting limits, the generalizability of the results. By giving suggestions to focused activities the paper adds to the advancement of compelling help for MSME Digital Marketing use. Creativity to utilize is discussed within the context of existing literature to confirm and challenge current thought and present the case for more research into MSMEs Creativity. Departing from the research model the influence of internet technology, Employee Skill, Digital strategy on Digital marketing on tourism culinary MSMEs. The value lies in the paper's use of empirical data derived from three separate methods of data collection and informed by the literature. This provides rich data to enable wider implications of the subject area to be discussed and contributes new perspectives to the MSME Digital Marketing utilize to discuss.
\end{abstract}

Keywords: Micro Small and Medium Enterprises, Digital Marketing, Culinary Tourism.

\section{Introduction}

The key goal of using marketing for organizations is to develop satisfying relationships with customers that benefit both the consumer and the producing company. Today, digital marketing is very important, regardless of size company business sector; It is therefore very important that the company not only uploads its website but also These efforts lead marketing to serve an important role within most organizations and society; as [1]. Marketing is the social process by which individuals get what they need and need through the creation and exchanging things and motivating force with others. As demonstrated by Forbes, 82 percent of clients did a direct investigation on the web, and (Tech Crunch) certified in one of their reports that 79 percent of people shop on the web; and as a real example [2] U.S. digital marketing spend will ascend to about $\$ 332$ billion by 2021 . All this leads to the fact more you are close 
to your customer; in other terms; the more you are connected with your customers, the more you will have to take into consideration the digital dimension of marketing strategies.

With billions of people worldwide connecting and using digital technologies, no doubt now is the right time to use digital marketing before it's too late. The importance of micro small and Medium Enterprises (MSME) for the economic growth of every country is widely acknowledged. There is a shortage of literature in digital marketing and research studies that observe different aspects of the MSME. However, most of the studies lack in digital marketing for example [3] implementing a holistic ERP system for SMEs, [4] digital marketing has been broadly used to advance the travel industry event advertisement, SMEs may take various courses to improve achievement when computerized change is changing their business models [5], does three people digital marketing a large company, but knowledge of how MSMEs utilize digital marketing requires more in-depth knowledge and only medium and large scale companies, there is still very little research on MSME especially digital marketing on culinary tourism in Indonesia.

The Ministry of Cooperatives and Small and Medium Enterprises (Kemenkop UMKM) propelled the same number of as 3.79 million smaller scales, little and medium undertakings (MSMEs) have utilized an online stage in showcasing their items. This number plays 8 percent of all current SMEs in Indonesia, which is 59.2 million and is assessed to speak to 80 percent of the overall monetary turn of events [6]. Computerized showcasing has likewise been broadly used to advance the travel industry around the globe [4], just rare sorts of people who effectively utilize web-based life as their promotion tools and they have not separated their online shop account with their account, several others use it occasionally, and the rest participants have never used social media marketing for being lack of technological skill. All participants showed great interest in using social media marketing continuously [7]. There is a significant correlation between sales revenue and the amount of time spent on social media marketing [8]. [9] The organizer of the International Culinary Tourism Association (ICTA), formed a paper in 2001, portraying its activity in the movement business. Characterized as a movement to "find out about or appreciate novel and essential eating-and-drinking encounters," culinary the travel industry is going into the standard of the American travel jargon.

The Culinary Industry is undergoing major changes to the foundations of globalization and sustainable urbanization and in satisfying the growing need for individual products [10]. Culinary tourism in Cirebon is important because it becomes a tourist destination, as a satellite city of major cities in Indonesia, and a complete infrastructure supports this culinary tour to progress and develops, among its toll roads, hotels, and other facilities. To understand this goal, digitalization is considered a central innovation [11]. As SMEs generally form the foundation of most economies, the achievement of computerized change will depend on the acceptance and implementation of advanced innovations in SMEs [10]. In this context, MSMEs have been transformed into digital information. Computerized changes have taken place step by step in various modern fields in "Industry 4.0" [12]. Nonetheless, this change is still at a moderate pace for SMEs [13]. The absence of sophisticated capabilities has become an overall concern among SMEs [3], which combines the absence of information and talent to implement innovations that are taking place [14].

Culinary tourism offers an authentic experience for the tourist and allows him to communicate with what is unique and original and radically linked to each country's history and distinctive culture [15], [16] recently, tourism is no longer confined to exploring tourist areas only, but a new type of tourism has become known as food and drink tourism, and this type is mainly based on exploring food and drink for a particular culture or country, or 
learning ways to prepare it, and trying the original taste of the dish in its home country [17]. Culinary tourism includes cooking classes at the hands of local food experts, as well as food and drink tours, whether in local restaurants and bars or farms and manufacturing places, as well as culinary festivals [18].

Digital marketing the operation designates all marketing actions passing through one or more digital channels more precisely Commercializing services and products through digital technologies, using the internet [19]. [20] also set extraordinary accentuation on the indevelopment search and how ICTs change vacationer conduct. In this context, one approach to move toward computerized culinary tourism and their conduct is to observe the advanced exercises that they can act according to their tourist exercises. The exercises that e-tourists can complete with advanced devices could be Information Technology (IT) [20], [21].

Furthermore, employee skills using digital marketing, the employee's skill in utilizing singular innovations and applications to incorporate the more extensive hierarchical measurements alluded to by [22]. The advancement of this culture and skills is basic, not least since IT selection, a focal supporting of digitalization requires talented skilled employees to create, receive and incorporate new and existing IT frameworks [23], [24]. [25] distinguish the advancement of ceaseless learning as necessary for building computerized capacities digital strategy [26].

The significance of digital strategy goes past perceiving the multiplication of computerized assets in practical zones, for example, activities, buying, and advertising [27]. A digital strategy perceives advanced assets in general [27], making and satisfying desires inside the association to gain new assets [28] on MSMEs.

As a result, the forms of advertising and marketing through new media depart in significant ways from the more familiar commercial advertising and promotion [29] seeks to provide as much visibility as possible online to maximize all opportunities for success. Mobile users are growing day by day and this is the most effective marketing method [30]. This is an opportunity that should not be missed. In this case, the factors of Information Technology, Employee Skill, and Digital Strategy are the three factors that are explored in the context of digital marketing at MSMEs can be seen in Fig. 1, On the other hand, talking about the case sector used in this study is culinary tourism. In the following section, we commencing our review of the literature, and after we highlight the methods adopted to search for a better understanding of the digital marketing on micro small and Medium Enterprises (MSMEs).

\section{Literature Review}

\subsection{Micro Small and Medium Enterprises (MSMEs)}

In Indonesia, MSMEs are not a homogenous gathering, yet extraordinary among subclasses. MEs and MIEs can be recognized clearly from MEs by reference to their various attributes in numerous viewpoints, for example, custom or routes in working together, showcase direction, social monetary profiles of the proprietors/makers, nature of laborers utilized, received association and the executive's framework, level of motorization (nature of creation process), wellsprings of principle crude materials and capital, area, outer connections, and level of ladies' contribution as business people [26]. [27] analyzed the degree of advancement of MSME in Indonesia, by concentrating on MSME bunches in the assembling business. From their perceptions, they arranged to assemble MSMEs groups in Indonesia into 
four sorts as indicated by their degree of improvement (counting level of the business enterprise), each with its attributes.

In Indonesia, the meaning of MSMEs is set in Law Number 20, 2008. In this law, the standards used to characterize an MSME as set out in Article 6 are net resource esteem barring area and working of business premises, or yearly deals. Under these measures, MIE is a specialty unit with a benefits estimation of at most 50 million Indonesian Rupiah (Rp) or yearly deals of greatest Rp300 million; SE is a specialty unit with an advantage estimation of more than Rp50 million up to a limit of Rp500 million or yearly deals of more than Rp.300 million up to a limit of Rp2.5 billion; and ME is an organization with a total assets estimation of more than Rp500 million up to a limit of Rp10 billion or yearly deals of over Rp2.5 billion to a limit of Rp50 billion. On the other hand, BPS receives the number of laborers as the rules: MIE: 0-4 people; SE: 5-19 people; ME: 20-99 people; and LE: $>99$ people [28].

\subsection{Culinary tourism}

Culinary tourism is the focus of food as an attraction for exploration and a destination for tourism. Although food has always been a part of hospitality services for tourists, it was not emphasized by the tourism industry until the late 1990s [29]. Culinary tourism can also generally refer to travel in which the goal is exploring and enjoying local delicacies and gaining memorable culinary experiences [9].

Related [30] that defined culinary tourism as follows: while traveling, tourists either purchase or consume local food or observe and research the process of food production (from agriculture to cooking schools), and view this as an important motivation for traveling or an important travel activity. Culinary tourism implies that local cultures that have interesting stories about their cuisines, and it also indicates that local or special knowledge and information that represent local culture and identities are being transferred [30]-[32]. Traveling without trying the local food of the country you are visiting will be an incomplete experience on a very large scale. Regardless, of your experience with the taste of food, whether you like it or not, but the magic happened when you start creating and formed a bond and developed a stronger relationship with that place and its inhabitants.

Countries where catering tourism has become very popular over the years. Whether they are domestic or foreign tourists, they all visit some cities and towns with only one goal in mind: to taste local food or get to know a specific city or region through the kitchen. The most effective way of cooking culture anywhere is tasting local food. However, many other activities offer local cuisine with cooking lessons. Another little way to visit the local and production markets is to produce unique products locally. According to [31] edited volume, Culinary Tourism uses the methods of folklore studies and anthropology to "explore food as both a destination and a vehicle for tourism".

This understanding of intangible heritage includes regional or local food not only as an expression of the region or locality's intangible heritage status but also as a marker of the culture and identity of the region. Likewise, there exists a growing recognition among researchers and the food industry of the increasingly close relationships between traditional food products and intangible heritage; linked to particular geographic areas and their specific gastronomic and culinary heritage, these relationships play an important role in (re)constructing and sustaining regional and local identities [33]-[35]. 


\subsection{Digital Marketing}

This term was first used in 1990; by more than 3 million people the world over. How mechanized advancing has made since the 1990s and 2000s has changed the way wherein brands and associations use development and propelled promotion for their marketing [36]. Digital marketing is characterized as:".... the advertising of items or administrations utilizing computerized channels to arrive at buyers ..." [37]. The key target is to advance brands through different types of computerized media. Advanced advertising is an umbrella for the promotion of items or administrations utilizing computerized and innovations, either the web or the web. Digital marketing is an umbrella for the marketing of products or services using digital and technologies, either the internet or the internet. The use of the internet includes websites such as Google, Facebook, Twitter, Linkedin, e-book, web-hosting, etc. Digital marketing of the web incorporates sites, for example, Google, Facebook, Twitter, Linkedin, digital book, web-facilitating, and so forth. Advanced showcasing which doesn't require the utilization of the web incorporates cell phones, show promoting, and some other computerized medium, for example, TV, communicate, LED-TV, satellite, and so on[37]

[38] uncovers that digital marketing is a term used to portray the incorporated advertising administrations used to draw in, connect with, and convert clients on the web. Digital marketing uses numerous channels, for example, content promoting, influencer showcasing, SEO, web-based life, and web-based publicizing to assist brands with interfacing with clients and reveal the exhibition of marketing programs continuously. How digital marketing has created since the 1990s and 2000s has changed how brands and organizations use innovation and computerized showcasing for their marketing [36], Digital marketing can target and control clients [39].

\subsection{Information Technology}

Information Technology is an umbrella term summing up mechanical gadgets with registering abilities that help dynamic and authoritative data preparation [14]. The innovation scene is a quick-moving one with new improvements including distributed computing [40] portable and investigative advancements [41] and interpersonal organizations [42]-[44] IT empowers correspondence, cooperation, and processing abilities to encourage the improvement of stages, computerized antiquities and advanced framework [45].

Be that as it may, while yielding valuable bits of knowledge, these examinations were not embraced in an SME-explicit setting, and there are noteworthy contrasts among SMEs and bigger firms. The arrangement challenge recognized by the [46] conveys an unmistakable appraisal: "The capacity of SMEs to quickly receive new advances, to learn by doing, improve, and enhance their creativity, is obliged by their little scope, restricting their capacity to receive the rewards of the computerized economy".

These difficulties, in any case, the development of programming as-an administration manages MSMEs' practical access to innovation [47] just as the adaptability to switch between advances as required, in this manner evading sunk expenses and lock-in to one IT supplier [46]. This presents MSMEs with an extraordinary chance to build up a high-caliber, versatile, and versatile IT foundation that can empower digital marketing. We hypothesize:

\section{H1: IT positively relates to the digital marketing of MSMEs.}

\subsection{Individual Skill}

The development of new advanced ancient rarities requires computerized abilities and the need to organize groups with a comparing advanced range of abilities [20]. Distributed 
computing, a transformative innovation, permitting MSMEs practical access to innovation, requires differing aptitudes in business, account, venture the board, agreement and merchant exchange abilities, and information coordination aptitudes [47]. From a progressively broad point of view, IT anticipates in MSMEs frequently flop because of an absence of senior administration support and helpless venture the executives' aptitudes [19].

SMEs need a blend of hard aptitudes, for instance, the capacity to utilize the innovation and break down higher volumes of information, just as the delicate abilities, for instance, tackling ineffectively organized issues, grasping change, ideation, and opportunity acknowledgment [48], [49]. Surviving exploration shows that workers' information and aptitudes, including basic reasoning, critical thinking capacities, and the capacity to team up in systems are on the whole fundamental to digitalization [49]. Worker aptitudes are pivotal to changing an organization's IT scene [49], [50]. It can in this way be hypothesized:

\section{H2: Employee skills positively relate to the digital marketing of MSMEs.}

\subsection{Digital strategy}

While MSMEs proprietor chiefs seldom build up a proper methodology except if completely required to do as such, discoveries show that organizations who are experiencing a change are bound to follow an arrangement [51] An advanced technique includes the change of items and administrations in blend with computerized advances taken from a businessdriven viewpoint [18], [52]. This incorporates esteem creation, esteem catch system, offer, advanced advances, key authoritative movements, and outside and inward drivers [18], [53]Reception of advanced innovations pervades the more extensive association, rises above existing conventional organization fringes, and requires a procedure to arrange the whole change to arrive at the characterized objective [18], [53].

The making of another offer is regularly a key yield of an advanced system that requires four measurements: (1) usage of computerized innovations, (2) change of significant worth creation instruments, and (3) hierarchical changes, which thus include (4) money related arranging [18], [50], [54]. Late exploration affirms that organizations require an advanced system to arrange every single compulsory asset to accomplish and improve intensity [53], [55]. Then again, the nonappearance of an advanced system prompts helpless choices and misuse of assets [56]. It can, therefore, be hypothesized:

\section{H3: Digital strategy positively relates to the digital marketing of MSMEs.}

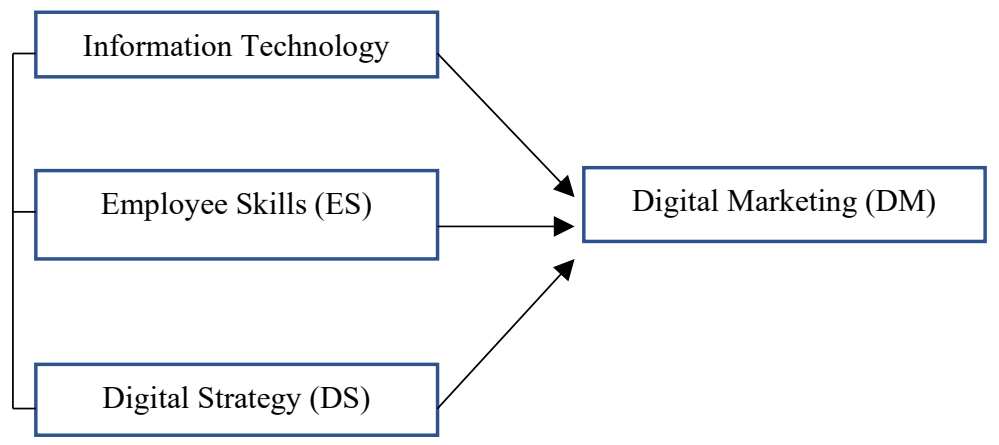

Fig.1. Research Model 


\section{Method}

Collecting contact information from the Department of Trade Industry of Cooperatives and UMKM (Disperindagkop-UMKM) Cirebon City, currently, there are 2.552 MSMEs in Cirebon City. From this number divided into various types of businesses, culinary businesses amounted to 1.404 MSMEs in the culinary field or about $55 \%$ of the population of the city of Cirebon MSMEs. The sample is part or representative of the population under study, To determine the size of the sample if the subject is less than 100, it is better to take all so that the research population research. If the subject is bigger, it can be taken between $20-25 \%$ [57] from this theory we took a sample of 351 respondents or equivalent to $25 \%$, the research sample in this study used random sampling.

The quantitative data was collected via an online survey, which was reviewed by two university academics and pre-tested by six university members. Comments on questions, sentence structure, wording, and consistency were considered for the final questionnaire to improve comprehensibility and validity. In March 2020, a link to the online survey was sent to 351 randomly selected SMEs by google form, resulting in 193 fully and correctly completed questionnaires. The overall response rate of $4.65 \%$ was similar to related studies in SME research [58].

\subsection{Measures}

Independent variables: The information technology variable (IT) was measured with the five-point Likert scale, ranging from 1 "strongly disagree" to 5 "strongly agree" as used by [50]. All items from the variable IT could be retained with factor loadings ranging from 0.739 to 0.803 [59]. The employee skills variable (ES) was measured with a 5-Point Likert scale ranging from 1 "strongly disagree" to 5 "strongly agree", adopted from [20], [50], [60]. The digital strategy variable (DS) was measured with a five-point Likert scale ranging from 1 "strongly disagree" to 5 "strongly agree" as adapted from [50].

Dependent variable: Digital marketing. Adopting the scale from [61]. Digital marketing (DM) was measured with a five-point Likert scale ranging from 1 "strongly disagree" to 5 "strongly agree".

\subsection{Operational variable}

a) Information Technology (IT)

IT1- To what extent does your organization use the following digital technologies? [43]

IT2- Social Media and Collaborative Technologies [50]

IT3- Mobile Technologies [41]

IT4- Data and Analytics [62]

IT5- Cloud Computing Services [63]

b) Employee Skills (ES)

ES1- We promote continuous learning of the unique properties of digital technologies [60]. ES2- The balance between overall digital skills \& specialized digital roles is adequate [50]. ES3- We can assemble teams with the right combination of skills for each digital project [20]. 
ES4- My organization provides the employees with the resources or opportunities to obtain the right skills to take advantage of digital trends [50].

c) Digital Strategy (DS)

DS1 - To what extent do you agree that the following are objectives of your organization's digital strategy? [50].

DS2 - Fundamentally transform business processes and/or business models (e.g., grow new lines of business) [50].

DS3 - Improve customer experience and engagement [50].

DS4 - Improve innovation [50].

DS5 - Improve business decision making [50].

DS6 - Increase efficiency (e.g., automation, timely access to expertise, and communities)

[50].

d) Digital Marketing (DM)

DM1- Using social media for advertising [61].

DM2- Branding that uses various web-based media such as blogs, websites, e-mail, AdWords [61].

\section{Result And Discussion}

The data sample consisted of simultaneous self-reported data from the same informants to assess the independent and dependent variables and as such it could represent a potential source of common method bias [64]. We conducted Harman's one-factor test where all items were subject to an EFA [64]. Common method variance was given if a single factor emerged from an unrotated factor solution or if the first factor explained more than $50 \%$ of the computed variance [64]. The analysis produced 17 factors above an eigenvalue of 1 , explaining $96.86 \%$ of the total variance. The first factor explained $36.01 \%$ of the variance. No single factor emerged, so a common method variance was not a major issue

[57] stated that FL $>0.5$ is acceptable, while [65] wants FL of at least 0.7. This time we use the opinion of Hair et al. (2006). It appears that all three variables have met the minimum FL requirements. The question is, are the four variables (Total_IT, Total_ES, and Total_DS) valid because minimum FL requirements have been met? Hair et al (2006) state that FL is not sufficiently used for validity testing. Two other criteria needed are average variance extracted and composite reliability. One more condition, namely discriminant validity is an additional requirement, but most researchers do not use it. The average variance extracted (AVE) is the average variance extracted by the program. Based on the extraction analysis results obtained an average of AVE of 0.648 .

Table 1. Average variance extracted (AVE)

\begin{tabular}{lcrl}
\multicolumn{1}{c}{ Var } & FL & \multicolumn{1}{c}{ VE } & AVE \\
\hline Total_IT & 0.849 & 0.72 & \\
Total_ES & 0.736 & 0.541 & 0.615 \\
Total_DS & 0.827 & 0.683 & \\
Total_DM & 0.718 & 0.515 & \\
\hline
\end{tabular}


The minimum AVE value that can be tolerated is 0.5 (Hair et al., 2006; Wijanto, 2008). Therefore, $\mathrm{AVE}=0.615$ meets the requirements.

Validity Test conducted by looking against Pearson (Pearson Correlation) compares with r-table with a significance of 5\%. And if the sample we use amounts to 193 correspondents, then the $\mathrm{r}$-value is 0.1191 . Where this value is obtained from $\mathrm{df}=\mathrm{n}-4, \mathrm{df}=193-4=189$. And if $\mathrm{r}$-table <rcount then accepted it is considered valid. Based on the results of statistical calculations each variable can be announced (in the Correction Item-Total Correlation column) $\geq 0.1191$ means that the data is valid. The highest validity on item question DS5 is 0.727 , and the lowest validity on item question ES3 is 0.496 .

Reliability testing used in this study is the Cronbach Alpha formula, while to find out the reliability test results to the statement plus the total score of each variable can be seen in the output. A research instrument has sufficient reliability if Cronbach's alpha coefficient is greater or equal to 0.70 .

Table 2. Reliability Statistics

\begin{tabular}{ccc} 
& Cronbach's Alpha \\
& Based on \\
& Standardized \\
Cronbach's Alpha & Items & N of Items \\
.914 & .915 & 17 \\
\hline
\end{tabular}

From the table above, it can be seen that the value of Cronbach's Alpha 0.914>0.70 means that the data is reliable data.

\subsection{Hypothesis testing}

T-test or partial test is used to test how the influence of each independent variable individually on the dependent variable. In this study the t-test is used to prove the hypothesis can be seen in the table below:

Tabel 4. Hypothesis testing

\begin{tabular}{ccccc}
\hline Variable & $\begin{array}{c}\text { Value of } \\
\text { Tcount }\end{array}$ & $\begin{array}{c}\text { Value of } \\
\text { Ttable }\end{array}$ & $\begin{array}{c}\text { a significance } \\
\text { level of } \boldsymbol{\alpha}\end{array}$ & Result \\
\hline $\begin{array}{c}\text { Information } \\
\text { Technology (IT) }\end{array}$ & 2.044 & 0.67576 & $5 \%$ & $\begin{array}{c}\text { Ho is rejected and } \\
\text { Ha is accepted }\end{array}$ \\
$\begin{array}{c}\text { Employee Skills } \\
\text { (ES) }\end{array}$ & 2.256 & 0.67576 & $5 \%$ & $\begin{array}{c}\text { Ho is rejected and } \\
\text { Ha is accepted }\end{array}$ \\
$\begin{array}{c}\text { Digital Strategy } \\
\text { (DS) }\end{array}$ & 5.33 & 0.67576 & $5 \%$ & $\begin{array}{c}\text { Ho is rejected and } \\
\text { Ha is accepted }\end{array}$ \\
\hline
\end{tabular}

F Test or Anova Test is a test to see how the influence of all independent variables together - the dependent variable. 
Tabel 5. F Test

\begin{tabular}{|c|c|c|c|c|c|c|}
\hline \multicolumn{7}{|c|}{ ANOVA $^{\mathrm{a}}$} \\
\hline & del & Sum of Squares & df & Mean Square & $\mathrm{F}$ & Sig. \\
\hline \multirow[t]{3}{*}{1} & Regression & 104.319 & 3 & 34.773 & 51.577 & $.000^{\mathrm{b}}$ \\
\hline & Residual & 127.422 & 189 & .674 & & \\
\hline & Total & 231.741 & 192 & & & \\
\hline \multicolumn{7}{|c|}{ a. Dependent Variable: Total_DM } \\
\hline
\end{tabular}

Judging from the results of the above table, we can know that the F test of the two independent variables is $51.577>\mathrm{F}$ table 2,86 or there is a relationship because the Sig level is 0,000 or smaller than $0.05(\mathrm{p}<0.05)$.

\subsection{Discussion}

This study contributes to a better understanding of the Digital marketing on micro small and Medium Enterprises (MSMEs) exactly inspecting the connection between the three key SME assets of IT, representative aptitudes, and advanced system, and digitalization, just as the effect of these assets and digitalization on budgetary execution. IT positively affects digitalization (H1). This proposes IT assets including portable innovations [66] web-based life [42], [43] shared advances, distributed computing administrations, and examination apparatuses add to the digitalization of SMEs. Expanding this discovering, [67] contend that remotely situated IT-based capacities greatly affect execution than inside IT-put together abilities which center concerning proficiency.

The discoveries additionally affirm surviving exploration [42] which shows that advanced explanatory devices permit SMEs to gauge bits of knowledge and streamline existing business forms [41], [68]. Versatile advances permit client connections to be created and offer new cooperation capacities [66]. Thus, [68] found that advanced diagnostic capacities decidedly identify with firm execution.

Worker abilities positively affect digitalization (H2), which affirms the discoveries of relatively late examinations showing that digitalization relies upon human capital just as mechanical assets [49], [69]. The appropriation of new computerized advancements regularly requires accomplished workers and the current writing recommends that gifted representatives are fundamental for troublesome digitalization [49]. Moreover, and dependent on a common excitement and advanced character [70] those representatives are integral to remaking esteems, standards, and authoritative conduct during the change procedure [23], [54].

Computerized methodology positively affects digitalization (H3), which is under earlier examination proposing that MSMEs experiencing a change procedure are bound to follow an arrangement, though not a proper system [51]. Digitalization influences the association on various levels: First, the personality of the association may change, with new standards and qualities that need to meet the desires for the various crowds of the changed endeavor [23], [54]; Second, digitalization challenges the ebb and flow plan of action and offer and goes about as a driver of further development [23], [71]. At long last, computerized advancements [48], upgrade the client experience, lead to business enhancements, and a positive change of the plan of action [71]. Digitalization additionally positively affects the money related execution of MSMEs (H4). Building new abilities through digitalization, in a business domain 
described by quick innovative change, can be a higher priority than planning. The capacity to incorporate, form, and reconfigure capabilities energizes new types of upper hand [72].

\section{Conclusion}

This study contributes adds as far as anyone is concerned about Digital Marketing on smaller scale little and Medium Enterprises (MSMEs) the assets that should be arranged for this change procedure to succeed. IT appropriation, worker aptitudes, and an advanced procedure essentially drive digitalization, and, thusly, digitalization drives the monetary exhibition of MSMEs. IT is legitimately and in a roundabout way recognized as a key factor affecting monetary execution employing digitalization. Earlier investigations have discovered IT as emphatically identifying with budgetary execution [19], [73], supporting our discoveries for the smaller scale little and Medium Enterprises setting. Be that as it may, MSMEs proprietor directors can likewise acquire an upper hand through both embracing IT and building computerized capacities to improve the viable organization of IT [74]. Information handling innovations, distributed computing administrations, versatile advances, and internetbased life channels are proper computerized advances that broaden, make, or change existing items and administrations for MSMEs, helping them arrive at a more extensive client base [47]. SME directors need to help and train representatives to get the fundamental digitalization aptitudes [49].

This will normally change their current jobs and influence the personalities of representatives and the character of the association in general [70]. Supervisors need to help workers to grow in like manner [75] and to make a personality and job inside the association identified with digitalization [71]. Administrators also need to put resources into computerized advancements to meet future client desires, for example, computerized administrations or items [76]. MSMEs chiefs will explicitly need to build up a computerized system with solid key execution pointers and activities to screen the change procedure. As the information proposes, digitalization doesn't bolster money related execution on each level, so a point by a point system and estimation plan will be valuable in recognizing unwanted turns of events.

This study has several limitations. Of all information gathered in have limited the speculation of the discovery. Carrying out this inspection in the city of Cirebon with the scope of culinary industry research, other topography will improve the quality and legitimacy of an unwavering estimation model. Relatedly extra examinations may likewise explore the exhibition result of various digitalization appropriation situations. a computerized showcasing basic given the development in the number of uses and advances accessible to MSMEs which computerized advances make the best commitment to money related execution? At last, as this dynamic marvel turns out to be progressively unpredictable and heterogeneous, future research could research what worker abilities are essential for the advanced change of MSMEs.

\section{References}

[1] P. B. Crosby, Quality is free: The Art of Making Quality Certain. New York: New American Library, 1979. 
[2] S. Digital, "Statista Digital Market Outlook The Statista Digital Market Outlook provides essential data for 8 digital markets in 150 countries," 2019.

[3] P. Kilimis, W. Zou, M. Lehmann, and U. Berger, "A survey on digitalization for SMEs in Brandenburg, Germany," IFAC-PapersOnLine, vol. 52, no. 13, pp. 2140-2145, 2019.

[4] I. G. A. O. Suryawardani and A. S. Wiranatha, "Digital Marketing in Promoting Events and Festivities. a Case of Sanur Village Festival," J. Bus. Hosp. Tour., vol. 2, no. 1, p. 159, 2017.

[5] H. Bouwman, S. Nikou, and M. de Reuver, "Digitalization, business models, and SMEs: How do business model innovation practices improve performance of digitalizing SMEs?,"

Telecomm. Policy, vol. 43, no. 9, p. 101828, 2019.

[6] D. Jutla, P. Bodorik, and J. Dhaliqal, “'Supporting the e-business readiness of small and medium-sized enterprises: approaches and metrics,"” Internet Res. Electron. Netw. Appl. Policy, vol. 12, no. 2, pp. 139-64, 2002.

[7] D. Purwana, R. Rahmi, and S. Aditya, "Pemanfaatan Digital Marketing Bagi Usaha Mikro, Kecil, Dan Menengah (UMKM) Di Kelurahan Malaka Sari, Duren Sawit,” J. Pemberdaya. Masy. Madani, vol. 1, no. 1, pp. 1-17, 2017.

[8] S. Aissi, P. Malu, and K. Srinivasan, "E-business process modeling: The next big step.," Computer (Long. Beach. Calif)., vol. 35, no. (5), pp. 55-62, 2002.

[9] W. Eric, "Culinary Tourism: A Tasty Economic Proposition.," 2002. .

[10] A. H. J. Lee, G. Wall, and J. F. Kovacs, "Creative food clusters and rural development through place branding: Culinary tourism initiatives in Stratford and Muskoka, Ontario, Canada," $J$. Rural Stud., vol. 39, pp. 133-144, 2015.

[11] H.-T. Chuang, "The rise of culinary tourism and its transformation of food cultures: The National Cuisine og Taiwan," Copenhagen J. Asian Stud., vol. 27, no. 2, pp. 84-108, 2009.

[12] A. de Jong and P. Varley, "Food tourism policy: Deconstructing boundaries of taste and class," Tour. Manag., vol. 60, pp. 212-222, 2017.

[13] F. X. Yang, I. K. A. Wong, X. S. Tan, and D. C. W. Wu, "The role of food festivals in branding culinary destinations," Tour. Manag. Perspect., vol. 34, no. March, p. 100671, 2020.

[14] B. Niranjanac and P. Mohan, "Digital Marketing in the Msme Sector of Kerala," University, 2018.

[15] D. Buhalis and R. Law, "Progress in information technology and tourism manage-ment: 20 years on and 10 years after the internet - the state of eTourism research.," Tour. Manag., vol. 29, no. 4, pp. 609-623, 2008.

[16] D. Buhalis, D. Leung, and R. Law, "eTourism: critical information and communication technologies for tourism destinations.," Destin. Mark. Manag. Theor. Appl., pp. 205-224, 2011.

[17] P. C. Verhoef et al., "Digital transformation: A multidisciplinary reflection and research agenda.," J. Bus. Res., 2019.

[18] C. Matt, T. Hess, and A. Benlian, "Digital transformation strategies.," Bus. Inf. Syst. Eng., vol. 57, no. 5, pp. 339-343., 2015.

[19] T. H. Nguyen, M. Newby, and M. J. Macaulay, "Information technology adoption in small business: Confirmation of a proposed framework.," J. Small Bus. Manag., vol. 53, no. 1, pp. 207-227., 2015.

[20] D. Nylén and J. Holmström, "Digital innovation strategy: A framework for diagnosing and improving digital product and service innovation.," Bus. Horiz., vol. 58, no. 1, pp. 57-67., 2015.

[21] R. Eller, P. Alford, A. Kallmünzer, and M. Peters, "Antecedents, consequences, and challenges of small and medium-sized enterprise digitalization," J. Bus. Res., vol. 112, no. September 2019, pp. 119-127, 2020.

[22] A. S. Bharadwaj, O. A. El Sawy, P. A. Pavlou, and N. Venkatraman, "Digital business strategy: Toward a next generation of insights.," MIS Q., vol. 47, no. 2, pp. 471-482, 2013.

[23] G. Fisher, S. Kotha, and A. Lahiri, "Changing with the times: An integrated view of identity, legitimacy, and new venture life cycles.," Acad. Manag. Rev., vol. 41, no. 3, pp. 383-40, 2016.

[24] Montgomery, Grier, Chester, and E. Al, "Food marketing in the digital age: a conceptual framework and agenda for research.," 2011. .

[25] N. Sadiku-Dushi, L. P. Dana, and V. Ramadani, "Entrepreneurial marketing dimensions and 
SMEs performance,”J. Bus. Res., vol. 100, no. December 2018, pp. 86-99, 2019.

[26] T. T. H. Tambunan, "Development of micro, small and medium enterprises and their constraints: A story from Indonesia," Gadjah Mada Int. J. Bus., vol. 13, no. 1, pp. 21-43, 2011.

[27] H. Sandee and J. ter Wingel., "SME Cluster development strategies in Indonesia: What can we learnfrom successful clusters?," Pap. Present. JICA Work. Strength. Capacit. SME Clust. Indones., 2002.

[28] T. Tambunan, "Recent evidence of the development of micro, small and medium enterprises in Indonesia," J. Glob. Entrep. Res., vol. 9, no. 1, 2019.

[29] L. M. Long, "Cultural politics in culinary tourism with ethnic foods," RAE Rev. Adm. Empres., vol. 58, no. 3, pp. 316-324, 2018.

[30] E. Ignatov and S. Smith, "Segmenting Canadian culinary tourists," Curr. Issues Tour., vol. 9, no. 3, pp. 235-255, 2006.

[31] L. Long, Culinary Tourism. Lexington: The University Press of Kentucky, 2004.

[32] S. Smith and H. Xiao, "Culinary tourism supply chains: a preliminary examination.," 2008.

[33] S. Everett and C. Aitchison, "The role of food tourism in sustaining regional identity: A case study of Cornwall, South West England," J. Sustain. Tour., vol. 16, no. 2, pp. 150-167, 2008.

[34] S. Labadi, "Introduction: Investing in cultural diversity," Int. Soc. Sci. J., vol. 61, no. 199, pp. $5-13,2010$.

[35] S. Kim and C. Iwashita, "Cooking identity and food tourism: The case of Japanese udon noodles," Tour. Recreat. Res., vol. 41, no. 1, pp. 89-100, 2016.

[36] B. Carter, B.Gregory, C. Frank, and S. B. Digital, Marketing for Dummies. John Wiley \& Sons, 2007.

[37] D. Ryan and C. Jones, Understanding Digital Marketing: Marketing Strategies for Engaging The Digital Generation. United States of America: Kogan Page Limited, 2009.

[38] R. I. Mogos, "Digital Marketing for Identifying Customers' Preferences: A Solution for SMEs in Obtaining Competitive Advantages".," Int. J. Econ. Pract. Theor., vol. 5, no. 3, pp. 240-247, 2015.

[39] E. Mogaji, T. O. Soetan, and T. A. Kieu, "The implications of artificial intelligence on the digital marketing of financial services to vulnerable customers," Australas. Mark. J., no. xxxx, 2020.

[40] P. K. Ross and M. Blumenstein, "Cloud computing as a facilitator of SME entrepreneurship.," Technol. Anal. Strateg. Manag., vol. 27, no. 1, pp. 87-101, 2015.

[41] A. Soroka, Y. Liu, L. Han, and M. S. Haleem, "Big Data driven customer insights for SMEs in redistributed manufacturing.," Procedia CIRP, vol. 63, pp. 692-697., 2017.

[42] S. Ainin, F. Parveen, S. Moghavvemi, N. I. Jaafar, and N. L. Mohd Shuib, "Factors influencing the use of social media by SMEs and its performance outcomes.," Ind. Manag. Data Syst., vol. 115 , no. 3, pp. 570-588, 2015.

[43] C.-W. Wu, "The performance impact of social media in the chain store industry.," J. Bus. Res., vol. 69 , no. 11 , pp. 5310-5316, 2016.

[44] F. Stănciulescu, G. C., Dumitrescu, "Optimizing the IT structures of tourism SMEs using modern applications and resources (Cloud).," Procedia Econ. Financ., vol. 15, pp. 1769-1778, 2014.

[45] S. Nambisan, "Digital entrepreneurship: Toward a digital technology perspectiveof entrepreneurship.," Entrep. Theory Pract., vol. 41, no. 6, pp. 1029-1055., 2017.

[46] OECD, "Key issues for digital transformation in the G20. Berlin, Germany.," 2017. [Online] Available: https://www.oecd.org/g20/key-issues-for-digital-transformation-inthe-g20.pdf. [Accessed: 03-Mar-2020].

[47] D. Assante, M. Castro, I. Hamburg, and S. Martin, "The use of cloud computing in SMEs.," Procedia Comput. Sci., vol. 83, pp. 1207-1212., 2016.

[48] T. Beliaeva, M. Ferasso, S. Kraus, and E. J. Damke, "Dynamics of digital entrepreneurship and the innovation ecosystem. 26(2)," Int. J. Entrep. Behav. Res., vol. 26, no. 2, pp. 266-284., 2019.

[49] M. J. Sousa and D. Wilks, "Sustainable skills for the world of work in the digital age.," Syst. Res. Behav. Sci., vol. 35, no. 4, pp. 399-405., 2018. 
[50] G. C. Kane, D. Palmer, A. N. Phillips, D. Kiron, and N. Buckley, "Aligning the organization for its digital future. 58(1)," MIT Sloan Manag. Rev., vol. 58, no. 1, pp. 3-27, 2016.

[51] R. A. Blackburn, M. Hart, and T. Wainwright, "Small business performance: Business, strategy and owner-manager characteristics.," J. Small Bus. Enterp. Dev., vol. 20, no. 1, pp. 8-27., 2013.

[52] R. A. Teubner, "Information systems strategy: Theory, practice, and challenges for future research.," Bus. Inf. Syst. Eng., vol. 5, no. 4, pp. 243-257, 2013.

[53] V. Grover and R. Kohli, "Revealing your hand: Caveats in implementing digital business strategy.," MIS Q., vol. 37, no. 2, pp. 655-662., 2013.

[54] D. A. Gioia, S. D. Patvardhan, A. L. Hamilton, and K. G. Corley, "Organizational identity formation and change.," Acad. Manag. Ann., vol. 7, no. 1, pp. 123-193., 2013.

[55] A. Yeow, C. Soh, and R. Hansen, "Aligning with new digital strategy: A dynamic capabilities approach. The,” J. Strateg. Inf. Syst., vol. 27, no. 1, pp. 43-58., 2018.

[56] T. Hess, C. Matt, A. Benlian, and F. Wiesböck, "Options for formulating a digital transformation strategy.," MIS Q. Exec., vol. 15, no. 2, pp. 123-139., 2016.

[57] J. Hair, Joseph E and E. Al., A Primer on Partial Least Squares Structural Equation Modeeling \{PLS-SEM). California. USA.: SAGE Publications,Inc., 2014.

[58] A. Kallmuenzer and U. Scholl-Grissemann, "Disentangling antecedents and performance effects of family SME innovation: A knowledge-based perspective.," Int. Entrep. Manag. J., vol. 13, no. 4, pp. 1117-1138., 2017.

[59] A. Field, Discovering statistics using IBM SPSS statistics: And sex and drugs and rock " $n$ " roll, 4th ed. 55 City Road, London: SAGE Publications Ltd., 2013.

[60] S. Aral and P. Weill, "IT assets, organizational capabilities, and firm performance: How resource allocations and organizational differences explain performance variation.," Organ. Sci., vol. 18, no. 5, pp. 763-780., 2007.

[61] R. Sanjaya and J. Tarigan., Creative Digital Marketing. Jakarta: PT Elex Media Komputindo, 2009.

[62] R. Jain, M. Tripathi, V. Agarwal, and J. Murthy, "Patent data analytics for technology benchmarking: R-based implementation," World Pat. Inf., vol. 60, no. April 2019, p. 101952 , 2020.

[63] B. Shojaiemehr, A. M. Rahmani, and N. N. Qader, "Cloud computing service negotiation: A systematic review," Comput. Stand. Interfaces, vol. 55, pp. 196-206, 2018.

[64] P. M. Podsakoff, S. B. MacKenzie, and N. P. Podsakoff, "Sources of method bias in social science research and recommendations on how to control it.," Annu. Rev. Psychol., vol. 63, pp. 539-569, 2012.

[65] P. Suliyanto, Metode Penelitian Bisnis untuk Skripsi, Tesis \& Disertasi. Yogyakarta: Andi Publisher, 2018

[66] S. Singh and J. Swait, "Channels for search and purchase: Does mobile Internet matter? J," ournal Retail. Consum. Serv., vol. 30, pp. 123-134, 2017.

[67] P. Neirotti and D. Pesce, "ICT-based innovation and its competitive outcome: The role of information intensity.," Eur. J. Innov. Manag., vol. 22, no. 2, pp. 383-404, 2018.

[68] S. F. Wamba, A. Gunasekaran, S. Akter, S. J.-F. Ren, R. Dubey, and S. J. Childe, "Big data analytics and firm performance: Effects of dynamic capabilities.," J. Bus. Res., vol. 70, pp. 356$365,2017$.

[69] M. Jandric and S. Randelovic, "Adaptability of the workforce in Europe: Changing skills in the digital era.," in Proceedings of Rijeka Faculty of Economics, 2018, pp. 36(2), 757-776.

[70] R. Bouncken and R. Barwinski, "Shared digital identity and rich knowledge ties in global 3D printing - A drizzle in the clouds?," lobal Strateg. J., vol. 55, no. 2, pp. 1-28, 2020.

[71] V. Fredrich, R. Bouncken, and S. Kraus, "The race is on: Configurations of absorptive capacity, interdependence and slack resources for interorganizational learning in coopetition alliances.," J. Bus. Res., vol. 101, pp. 862-868., 2019.

[72] D. J. Teece, "A capability theory of the firm: An economics and (strategic) management perspective.," New Zeal. Econ. Pap., vol. 53, no. 1, pp. 1-43., 2019.

[73] A. Behera, N. Nayak, and H. Das, "Performance measurement due to IT adoption.," Bus. 
Process Manag. J., vol. 21, no. 4, pp. 888-907, 2015.

[74] H. Mao, S. Liu, J. Zhang, and Z. Deng, "Information technology resource, knowledge management capability, and competitive advantage: The moderating role of resource commitment.," Int. J. Inf. Manage., vol. 36, no. 6, pp. 1062-1074., 2016.

[75] M. Fitzgerald, N. Kruschwitz, D. Bonnet, and M. Welch, "Embracing digital technology: A new strategic imperative.," MIT Sloan Manag. Rev., vol. 55, no. 2, pp. 2-12, 2014.

[76] M. M. Davis, J. Field, and E. Stavrulaki, "Using digital service inventories to create customer value.," Serv. Sci., vol. 7, no. 2, pp. 83-99., 2015. 